\title{
Insulamento burocrático, inserção social e políticas públicas no Brasil: o caso do CrediAmigo
}

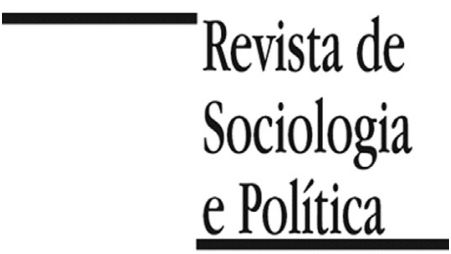

DOI 10.1590/1678-987316245901

\author{
Silvio Salej Higgins e Jorge Alexandre Barbosa Neves
}

\begin{abstract}
Resumo
O artigo analisa a proposta metodológica do CrediAmigo, programa de Microcrédito do Banco do Nordeste (BNB). Visamos identificar os fatores organizacionais que tornam viável a proposta do ponto de vista financeiro e social. O trabalho utiliza dois tipos de dados: secundários, sobre os montantes e inadimplência da operação (fornecidos pelo BNB), e primários, fruto de observação participativa do processo de operação, aplicação da metodologia e percepções dos próprios clientes. O principal achado sustenta a hipótese do insulamento burocrático e da inserção social. O BNB só consegue viabilizar a operação após um longo processo de aprendizado, no qual foi criado um corpo burocrático ad hoc, diferente dos funcionários de carreira do Banco, gerenciado por uma Organização Não Governamental, o Instituto Nordeste Cidadania (INEC), fundada pelo próprio BNB. A burocracia do INEC tem um perfil de formação adaptado aos setores sociais que subsistem na economia informal. Os resultados ampliam a unilateralidade de outros estudos sobre o CrediAmigo. Do ponto de vista sociológico, concluímos que a dimensão institucional-organizativa é um fator-chave para explicar a viabilidade da operação do microcrédito. Muito além da ideia simples de que as organizações só reduzem custos de transação, as instituições forjam aprendizados e criam habilidades de trabalho em seus funcionários.
\end{abstract}

PALAVRAS-CHAVE: microcrédito; insulamento burocrático; inserção social; política social; CrediAmigo.

Recebido em 27 de Janeiro de 2015. Aceito em 24 de Abril de 2015.

\section{Introdução ${ }^{1}$}

\author{
1 Agradecemos aos \\ comentários e sugestões dos \\ pareceristas anônimos da \\ Revista de Sociologia e \\ Política.
}

$\mathrm{O}$ presente trabalho parte de uma pergunta simples, mas cuja resposta não tem sido amplamente buscada por parte dos formuladores e avaliadores brasileiros em política social. Como pode ter dado certo o programa CrediAmigo do Banco do Nordeste (BNB), de longe o mais exitoso programa de microfinanças brasileiro? Não obstante, destacamos dois estudos pioneiros que colocam sob a lupa as intervenções do BNB no mercado de microfinanças. Abramovay (2008) avalia o desenho do crédito rural destinado ao segmento mais pobre dos agricultores familiares (PRONAF B) com o intuito de encontrar os fatores da alta inadimplência nestes serviços de crédito, ao mesmo tempo em que analisa as propostas alternativas do Agroamigo e do Crediamigo Comunidade, linhas de microcrédito rural do BNB, focando um fator essencial destas soft-technologies: a relação entre cliente e agente de crédito. O presente estudo vai ao encontro das conclusões de Abramovay no sentido de que este destaca o papel fundamental do agente de crédito na construção de instituições self-enforcing que reduzem a inadimplência, isto é, onde a teia de relações pessoais entre o cliente e o agente de crédito faz emergir os mecanismos do capital social: fluxos de informação, sentido do dever de retribuir o que foi emprestado e controle social lateral entre os beneficiários. Porém, vamos além deste achado na medida em que nos aprofundamos na estrutura burocrático-institucional na qual ganha destaque o agente de crédito. Por sua vez, o minucioso estudo de Neri (2008) sobre o impacto e a metodologia do CrediAmigo tampouco foca o fator burocrático. Talvez, Neri e sua equipe não estivessem obrigados a incorporar o viés burocrático-institucional, dado seu foco sobre o impacto do 
2 Aqui, vale a pena citar as palavras do próprio Weber (1980, p.16): "Num Estado Moderno, necessária e inevitavelmente, a burocracia realmente governa, pois o poder não é exercido por discursos parlamentares nem por proclamações monárquicas, mas através da rotina da administração". programa e dados os pressupostos de racionalidade microeconômica dos modelos empregados em sua avaliação. Todavia, o fato é que o referido estudo deixa uma importante lacuna que precisa ser preenchida pela pesquisa sociológica.

Diante dessas unilateralidades, consideramos pertinente, para analisar o CrediAmigo, adotar ferramentas do programa de pesquisa neoinstitucional (Bates 2005; Block \& Evans 2005) sobre o papel do Estado-Nação na criação de condições para o desenvolvimento econômico e o bem-estar dos cidadãos. Empregamos a mesma hipótese que levanta Evans quando estuda as relações entre burocracias de Estado e agentes privados para a implementação de políticas industriais. Na economia política de Evans ganha destaque um ator que, normalmente, foi deixado de lado pelas teorias marxistas do Estado capitalista: a burocracia eficiente (Block 1988). Dito sem rodeios, o foco weberiano nas burocracias de Estado é mais útil na compreensão e entendimento do Estado capitalista que as próprias teorias de classe do marxismo. Assim, do ponto de vista sociológico, quem diz "Estado" diz "corpos burocráticos"2.

Burocracias eficientes conseguem criar condições de desenvolvimento econômico e bem-estar social mediante um duplo mecanismo: insulamento e parceria (Evans 2004). O primeiro preserva-as frente à voracidade dos agentes privados atuantes no mercado; o segundo permite-as agir com a mística necessária para desatar confiança e cooperação com o setor privado - como apontam as pesquisas de Evans - e com o setor informal ou popular - como aponta o presente trabalho. Assim, a pergunta sobre como deu certo o CrediAmigo exige explicitar os mecanismos de insulamento burocrático do programa e de parceria com seu alvo: a população de baixa renda que sobrevive no setor informal da economia.

Com essa finalidade, o presente trabalho segue a seguinte ordem expositiva: em primeiro lugar, caso o leitor não esteja familiarizado com o microcrédito, apresentamos o que há de inovador na metodologia criada por Muhammad Yunus para levar o serviço do crédito à população mais empobrecida de Bangladesh (Yunus \& Jolis 2006). Em segundo lugar, expomos a evolução do marco regulatório brasileiro para a política pública de microcrédito, dando destaque ao fato de que o CrediAmigo se torna o catalisador da nova política de microcrédito do Governo Dilma Roussef - o Programa Crescer, lançado em 2011. Em terceiro lugar, testamos a hipótese de Evans e apresentamos as evidências empíricas que a tornam uma leitura válida do êxito do programa. Finalmente, sintetizamos as principais descobertas de nosso estudo.

Em termos do desenho metodológico, o presente estudo é um case study, um estudo em profundidade do CrediAmigo. Nesse sentido, não há nenhuma lógica ou pretensão inferencial. Não visamos concluir por que dão certo, ou fracassam, do ponto de vista institucional, os inúmeros programas de microcrédito que existem no mundo afora. Nossa busca foi bem mais modesta, ao focar uma inovação institucional de um típico banco desenvolvimentista brasileiro: o BNB. Os dados primários que sustentam nosso estudo foram coletados mediante observação participante junto aos agentes de crédito do CrediAmigo e funcionários do Instituto Cidadania (INEC), durante visita técnica à sede do Banco do Nordeste em Fortaleza (CE), realizada em novembro de 2011. Na busca de informantes-chave e na coleta de informações secundárias, foi de vital importância nossa participação, ao longo de dois anos (2010-2012) na Rede Mineira de Microcrédito, fórum liderado pela Secretaria de Trabalho e Emprego do Governo do Estado de Minas Gerais. A Rede propiciou as oportunidades para conhecer atores do setor financeiro, gestores públicos e membros de organizações sociais com ampla experiência na prática das microfinanças. 


\section{O método Grameen como ponto de referência incontornável}

${ }^{3}$ Grameen, termo da língua bengali, pode ser traduzido como "rural" ou "da aldeia" (Yunus 2006)

\footnotetext{
4 Em julho de 2013, por exemplo, um cartão de crédito do Banco do Brasil, entre seus encargos financeiros, tinha um crédito rotativo cuja taxa era $4,70 \%$ ao mês que, somados ao IOF (Imposto sobre Operações Financeiras) de $0,30 \%$ ao mês, somava $77,75 \%$ anuais. Na atualidade, as operações de microcrédito no Brasil não ultrapassam, em média, $1 \%$ de juro mensal.
}

O prêmio Nobel de Paz, concedido de forma compartilhada a Muhammad Yunus e ao Grameen Bank de Bangladesh, em 2006, deu fôlego e visibilidade internacional ao tema das microfinanças ${ }^{3}$. Sem cair na mistificação, o método de crédito Grameen, pioneiro na inovação microfinanceira, tem demonstrado sua eficácia na luta contra a pobreza: em 2007 contava com sete milhões de clientes, tinha uma taxa de $2 \%$ de inadimplência e tirava da linha de pobreza 250 mil pessoas por ano (Daley-Harris 2007). Porém, somos conscientes de que o acesso ao crédito não é uma condição suficiente para uma saída irreversível da pobreza. Ter crédito é só uma condição necessária. Saneamento básico, acesso à educação, sistema de saúde e estabilidade política, entre outros fatores, não estão nas mãos de um banco que pratique o microcrédito.

Em primeiro lugar, no método Grameen o que define o microcrédito não é o prefixo. Não se trata de um crédito, em sentido habitual, por um montante pequeno. Nas aldeias pobres de Bangladesh ou nas favelas a usura outorga um crédito pequeno que explora a necessidade do tomador. Já se olharmos as taxas de juros não há muita diferença, por exemplo, entre o que cobra um usurário e um cartão de crédito no Brasil ${ }^{4}$. O que torna alternativo o microcrédito é a natureza da relação social: trata-se de uma relação social alternativa.

Em segundo lugar, Yunus fez o que parecia impossível aos olhos dos bancos tradicionais: emprestar sem caução. Na raiz do fenômeno, o diagnóstico de Yunus diverge de um economista como De Soto (2001). Este último considera que o problema dos pobres é de falta de titulação de direitos de propriedade sobre seus bens primários (o barraco onde mora ou o pedaço de terra onde trabalha). Mas, para Yunus, o problema reside em acreditar nas capacidades das pessoas; o recurso principal é a própria pessoa. O sistema bancário standard devassa o passado do tomador em busca de informações que reduzam o risco do empréstimo ao mesmo tempo em que exige garantias reais. Já o microcrédito, ao contrário, enxerga o futuro das pessoas pobres que não têm nada a dar em garantia (Yunus 2011).

Em terceiro lugar, do ponto de vista institucional, é o Grameen quem busca seus clientes e não o contrário. No limite, Yunus entendeu que o crédito alternativo tinha de ser uma experiência itinerante; poder-se-ia até dizer apostólica, onde as equipes do Grameen buscavam seus clientes nas aldeias mais afastadas de Bangladesh.

Em quarto lugar, após um longo processo de tentativa e erro, a equipe de Yunus aferiu o dispositivo organizativo que aprofunda o caráter do microcrédito como relação social alternativa: o grupo de crédito. Além de testar a quantia e regularidade dos pagamentos de devolução, o Grameen descobriu que o controle social lateral era o melhor mecanismo que dispensava também o devedor solidário tradicional. Pelo esquema do grupo, quando um membro deixa de fazer seus depósitos, impede que os outros obtenham crédito. Desta forma cria-se um custo compartilhado que desata mecanismos informais de sanção e estimula a mutualidade (Gráfico 1). O método demonstrou ser efetivo, pois a inadimplência do Grameen não ultrapassa $2 \%$, na média histórica.

\section{Marco regulatório do microcrédito no Brasil: do PNMPO ao Programa Crescer}

A história da regulação brasileira do negócio financeiro é curiosa, para dizer o mínimo. Por uma parte, até final dos anos 1990 havia uma lei contra a usura que penalizava a cobrança de taxas de juros acima de $12 \%$ ao ano, aplicada aos agentes financeiros não regulamentados (Mick 2003). Mas, por outra parte, os serviços bancários formais e as taxas de juros continuam entre os mais caros do 
Gráfico 1 - Banco Grameen: o microcrédito como relação social alternativa

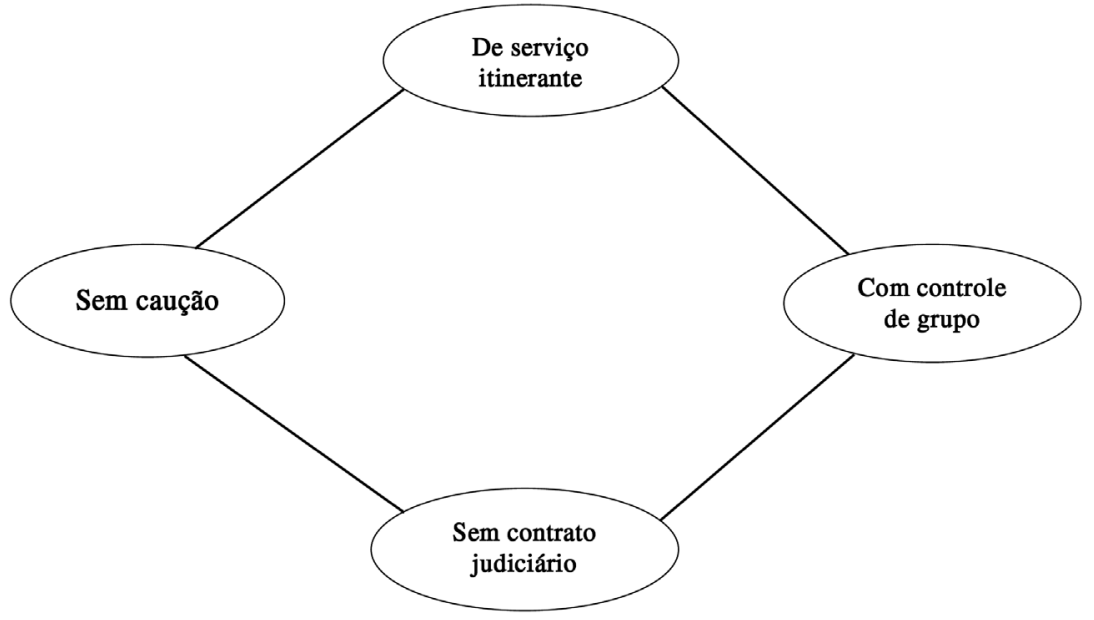

Fonte: os autores.

mundo. Até 2005 o sistema financeiro era bimodal: por um lado, as finançascamelôs eram ilegais, por outro, os serviços eram caros e com baixa cobertura social.

Ainda que tenhamos notícias sobre experiências com finanças solidárias nos anos 1970 do século passado, a abertura da legislação brasileira para o fenômeno do microcrédito começa na virada do século XXI (Mick 2003). Há três passos-chave neste processo. Em primeiro lugar, a Lei n ${ }^{\circ} 9.790$, de 23 de março de 1999, criou a Organização da Sociedade Civil de Interesse público (OSCIP), facultada para emprestar serviços financeiros alternativos. Até aquele momento, os serviços de microfinanças eram oferecidos por ONGs que operavam tecnicamente na ilegalidade, ao teor da lei da usura. Em segundo lugar, o Conselho Monetário Nacional, através da Resolução 2.627, de 1999, criou a figura da Sociedade de Crédito ao Microempreendedor (SMC), à qual está permitida a distribuição de lucros aos investidores em microcrédito. Porém, as SMC não estão habilitadas para captar poupança e recolher depósitos. Em terceiro lugar, o primeiro governo Lula assume como política a democratização do acesso aos serviços financeiros e, para tal, cria em 2003 o Banco do Povo, filial do Banco do Brasil, que oferecia serviços de acesso simplificado e créditos pequenos à população de baixa renda. Com este mesmo propósito, entre outras iniciativas regulatórias, foi promulgada a Medida Provisória 226, de 29 de novembro de 2004, que instituiu o Programa Nacional de Microcrédito Produtivo Orientado (PNMPO), no âmbito do Ministério do Trabalho e Emprego.

$\mathrm{Na}$ prática, o grande impulso do PNMPO às microfinanças alternativas residiu em que recursos do Fundo de Amparo ao Trabalhador (FAT) e 2\% de todos os depósitos à vista podiam ser alocados em operações de microcrédito, sob pena de retenção do saldo não utilizado, sem nenhuma remuneração, pelo Banco Central. Os intermediários destes recursos foram bancos de segundo andar, como o Banco Nacional de Desenvolvimento (BNDES) e o Banco de Desenvolvimento do Nordeste (BNB). Estes, por sua vez, liberavam recursos em instituições prestadoras de serviços financeiros alternativos, como as OSCIPs e as SMC, entre outras ${ }^{5}$. Por esta via, encontrou-se uma saída à falta de liquidez que impõe a este tipo de organizações a proibição de captar poupança e depósitos.

O processo de abertura gradual da legislação foi, em parte, o resultado da pressão política do terceiro setor focado na prestação de serviços financeiros 
${ }^{6} \mathrm{O}$ aporte previdenciário é de aproximadamente $\mathrm{R} \$ 50$ mensais.

\footnotetext{
${ }^{7}$ O compulsório bancário designa o montante de depósitos a vista, de todos os bancos comerciais, que fica retido diariamente no Banco Central.
}

alternativos. A constituição, em 2002, da Associação Brasileira dos Dirigentes de Entidades Gestoras e Operadoras de Microcrédito, Crédito Popular Solidário e Entidades Similares (ABCRED) foi um passo importante na articulação social e política dos agentes de microfinanças. Aliás, pela pressão desta associação o conceito de microcrédito produtivo orientado constituiu-se na espinha dorsal do PNMPO. Por um lado, o conceito liberava recursos de crédito a setores tradicionalmente excluídos (economia informal) e, por outro, focava o processo de acompanhamento técnico ao tomador do crédito (plano de negócios, contabilidade técnica etc.).

Após a criação do PNMPO, várias iniciativas foram promovidas como forma de melhorar o ambiente das microfinanças no país. Em primeiro lugar, em função de ampla mobilização dos micro e pequenos empresários, foi simplificado o regime de tributação das pequenas e médias empresas, mediante a Lei Complementar $n^{\circ} 123$, de 2006, mais conhecida como a Lei do Supersimples. Em segundo lugar, criou-se a figura do microempreendedor individual, mediante a Lei Complementar $n^{\circ}$ 128, de 19 de dezembro de 2008. Esta incentiva a regularização dos microempreendedores que se encontram na informalidade ao conceder benefícios da Previdência Social em troca de pequenos aportes mensais ${ }^{6}$. Em terceiro lugar, a Lei ${ }^{\circ} 12.087$, de 11 de novembro de 2009, autorizou a aplicação de até R \$ 4 bilhões dos cofres do Governo Federal aos fundos garantidores de crédito destinados a micro e pequenas empresas (Gráfico 2).

Em valores absolutos, o PNMPO demonstra resultados crescentes, pois ao longo de sete anos de existência já liberou, cumulativamente, quase R \$ 17 bilhões. Se levarmos em conta que no Brasil a massa monetária do compulsório bancário é de aproximadamente R $\$ 380$ bilhões, os $2 \%$ que a lei manda aplicar anualmente em operações de microcrédito seriam quase $\mathrm{R} \$ 7,6$ bilhões ${ }^{7}$. Pelos dados do Gráfico 2, entre 2011 e 2012 houve um salto expressivo de $40 \%$ no montante de recursos liberados para microcrédito produtivo orientado, atingindo um total de $\mathrm{R} \$ 6,23$ bilhões, o que equivale a $81 \%$ dos recursos disponíveis do compulsório bancário. Este total foi aplicado em 3,85 milhões de operações, o que dá uma média de R $\$ 1.621$ de crédito por operação.

Gráfico 2 - PNMPO. Concessão de crédito 2005-2012

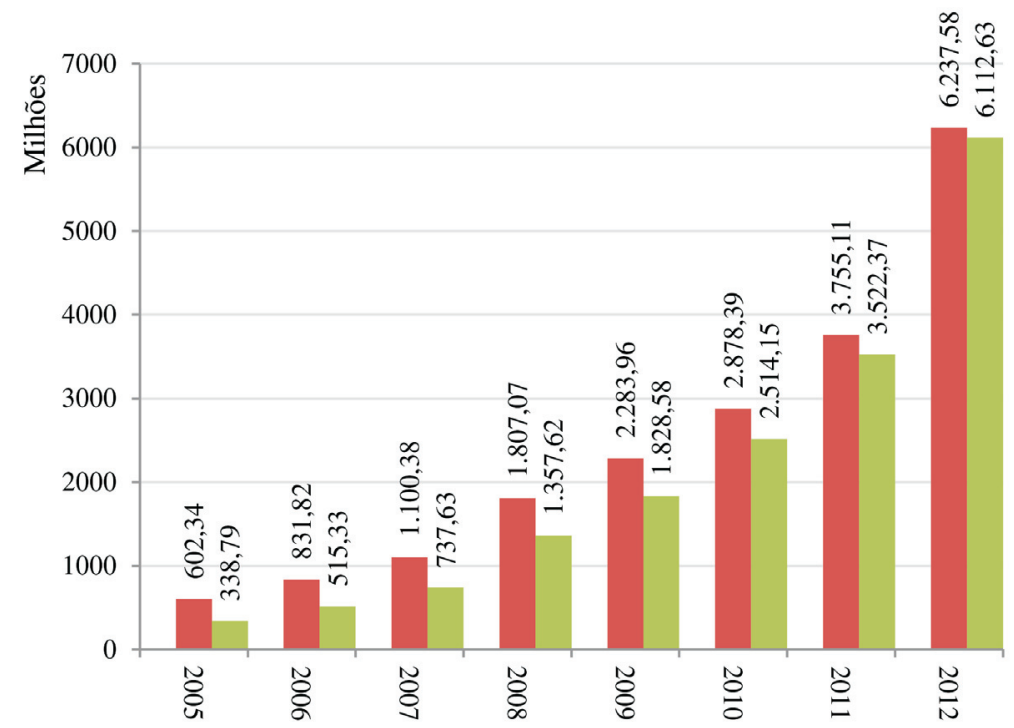

Fonte: os autores, a partir do relatório do Ministério do Trabalho e Emprego (2013). 


\section{Perfil metodológico do microcrédito no Brasil}

Com base apenas nos questionários elaborados pela Microfinance Exchange Information (MIX 2012), entre as 26 instituições respondentes, Barone e Martinez (2009) identificaram que no Brasil o crédito individual e o grupo solidário dominavam o mercado. Conforme o gráfico 2, do ponto de vista dos empréstimos ativos, o grupo solidário correspondia a 52,4\% da modalidade dos empréstimos ativos e, do ponto de vista do montante da carteira, cerca de $64 \%$ correspondiam a créditos individuais. O Banco Comunal é uma nova metodologia na qual o tomador de crédito é uma comunidade mais ampla, por exemplo, um grupo de famílias, que recebe um montante determinado para projetos produtivos (Gráfico 3). O grupo se auto-organiza e determina as condições de participação e as obrigações mútuas. Cabe ao agente de crédito monitorar e acompanhar o processo. De fato, o CrediAmigo rural começou a trabalhar de forma maciça neste novo esquema ${ }^{8}$.

Ao analisar comparativamente as metodologias de microcrédito no contexto latino-americano (Gráfico 4), o Brasil aparecia como único país onde o grupo solidário tem presença significativa como parte da oferta de serviços financeiros, dentre as Instituições de Microfinanças (IMFs) pesquisadas. Como ficará exposto adiante, a notória diferença do Brasil, na hora de implementar o grupo solidário, deve ser atribuída ao CrediAmigo do Banco do Nordeste.

\section{IV.1. CrediAmigo: a experiência de êxito no Brasil}

${ }^{8}$ O Crédito Solidário designa o aval ancorado num grupo de tomadores de crédito que se apoiam mutuamente. De ordinário, esta é uma exigência imposta pelo credor. Já o Banco Comunal é um arranjo mais amplo que envolve a autogestão de um grupo sobre o destino e administração de um crédito. $\mathrm{O}$ grupo pode ou não decidir pelo aval solidário.
De longe, a experiência organizacional de maior sucesso no mercado do microcrédito brasileiro (Gráfico 5) é o CrediAmigo, linha de negócios microfinanceiros do Banco do Nordeste (BNB).

"Dadas as características de aval solidário, sustentabilidade, retorno privado, retorno social (leia-se emancipação da pobreza), foco e retorno das mulheres e ao fato de ocupar mais de $60 \%$ do mercado brasileiro de microcrédito, o Crediamigo pode ser considerado o autêntico Grameen tupiniquim" (Neri \& Da Silva 2005, p.21).

A principal diferença entre o Grameen e o CrediAmigo está na área de atuação: o primeiro atua no meio rural enquanto o segundo atua essencialmente no meio urbano. A história do CrediAmigo começou em 1997, depois que um grupo de funcionários do Banco do Nordeste do Brasil (BNB) visitou organizações de microcrédito do país e do exterior, Porto Sol (Brasil), Banco Sol (Bolívia), Mibanco (Peru), Banco do Estado do Chile e Banco Rakyat Indonésia. Após conhecer essas iniciativas, ainda em 1997, foi lançado o projeto

Gráfico 3 - Distribuição de empréstimos ativos e de carteira no Brasil

Distribuição de empréstimos

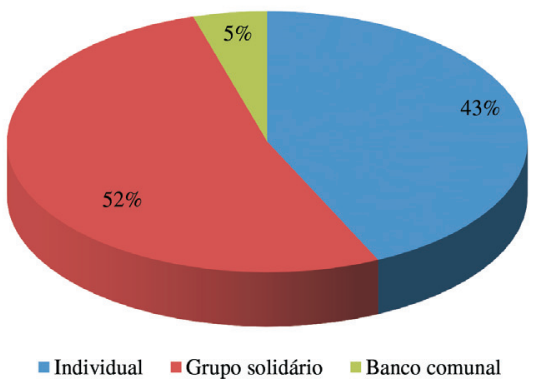

Distribuição de carteira

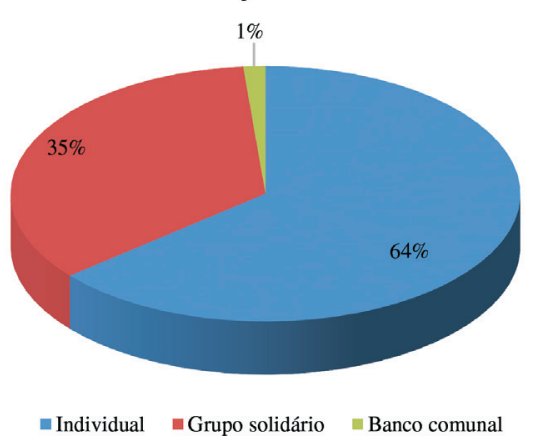

Fonte: MIX (2008); Barone e Martinez (2009). 
Gráfico 4 - Metodologias de Microcrédito na América Latina

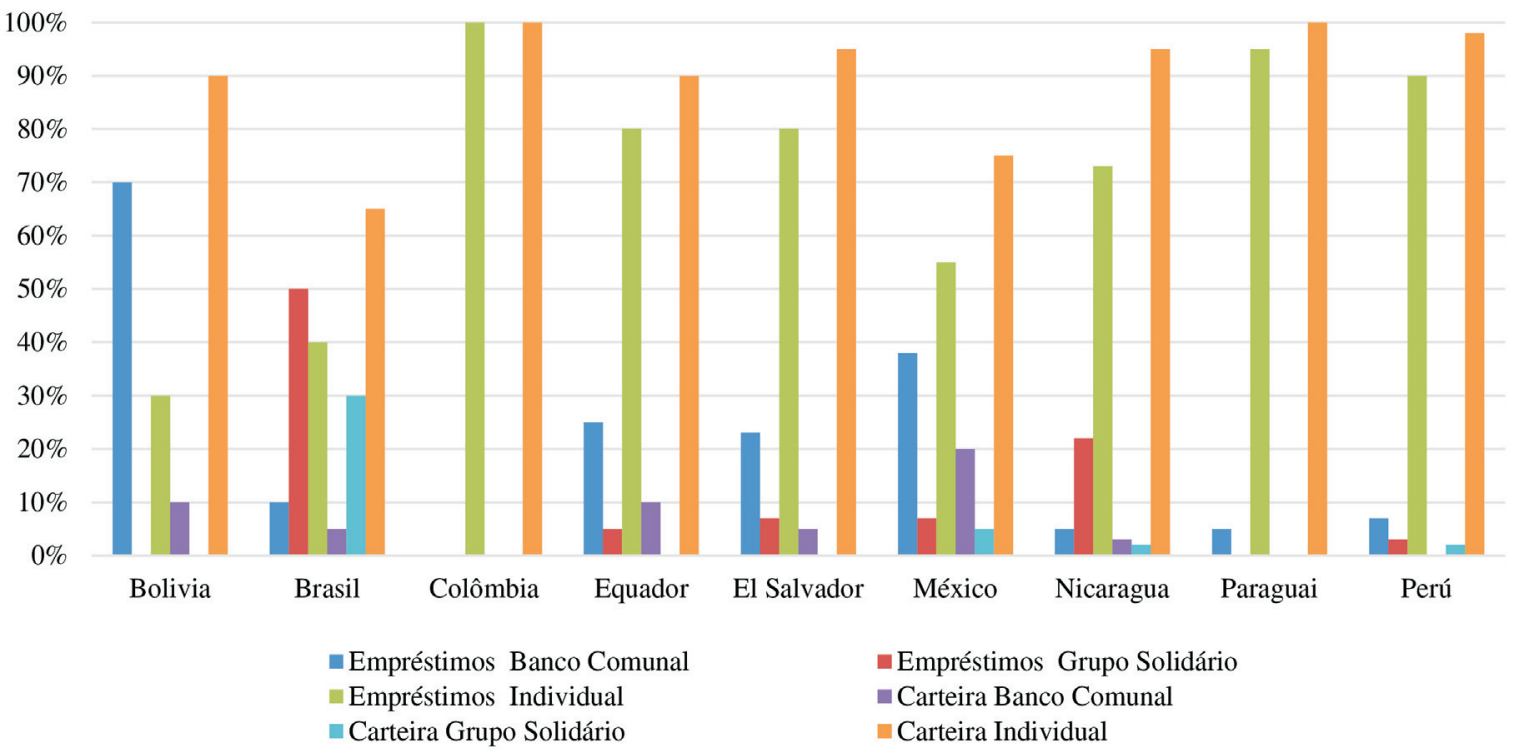

Fonte: Barone e Martinez (2009).

Gráfico 5 - Principais operadores de microcrédito (Brasil, acima de US\$ 5 milhões, 2012)

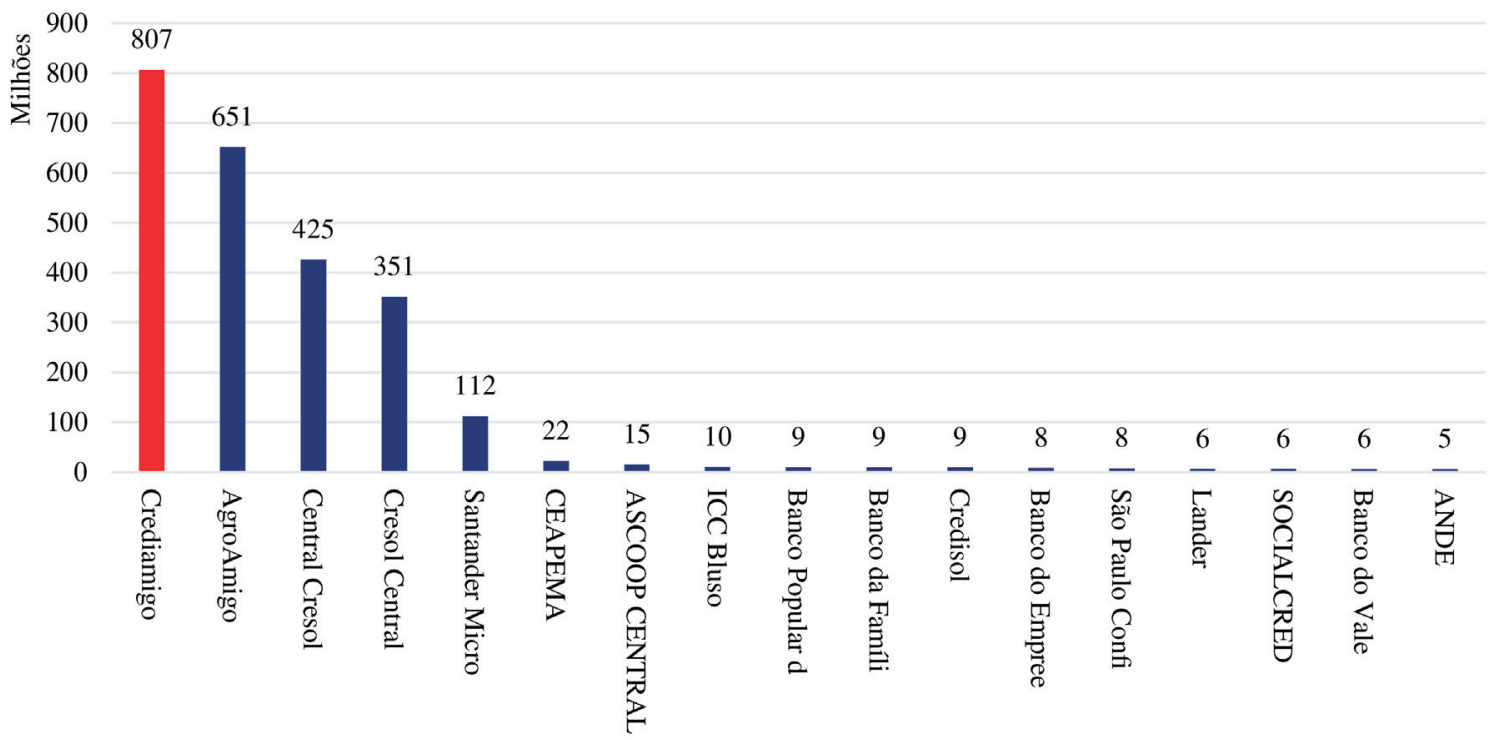

Fonte: Os autores.

piloto do programa, com a implantação de unidades em cinco cidades do Nordeste: Fortaleza, Itabuna, Recife, São Luis e Aracajú.

Em 1998, ano de criação do CrediAmigo, foram abertos mais postos de atendimento, dando início a uma ampla difusão do programa pelo Brasil. Em 2011, o CrediAmigo possuia 314 unidades de atendimento (cada unidade agrupa vários postos) e estava presente em 1.878 municípios dos 5.570 que compõem o território brasileiro. A maioria das unidades se encontra no Nordeste, sendo apenas 24 fora dessa região. As unidades, por sua vez, estão subdivididas em 173 agências e 189 postos de atendimento. 
Os principais resultados na evolução da operação estão resumidos nos Gráficos 6, 7, 8 e 9, a seguir.

Em 2008, a Fundação Getúlio Vargas publicou o mais completo estudo já feito sobre o impacto socioeconômico do CrediAmigo. Coordenado pelo economista Marcelo Neri, e com a base de dados dos clientes à disposição, o estudo demonstra, sob diversos ângulos, a eficiência do programa. Eis alguns dos achados mais relevantes:

(1) Índices de saída de pobreza: 60,8\% para linha de pobreza da Fundação Getúlio Vargas (FGV), 50\% para a linha de pobreza do

Gráfico 6 - CrediAmigo: evolução de clientes ativos

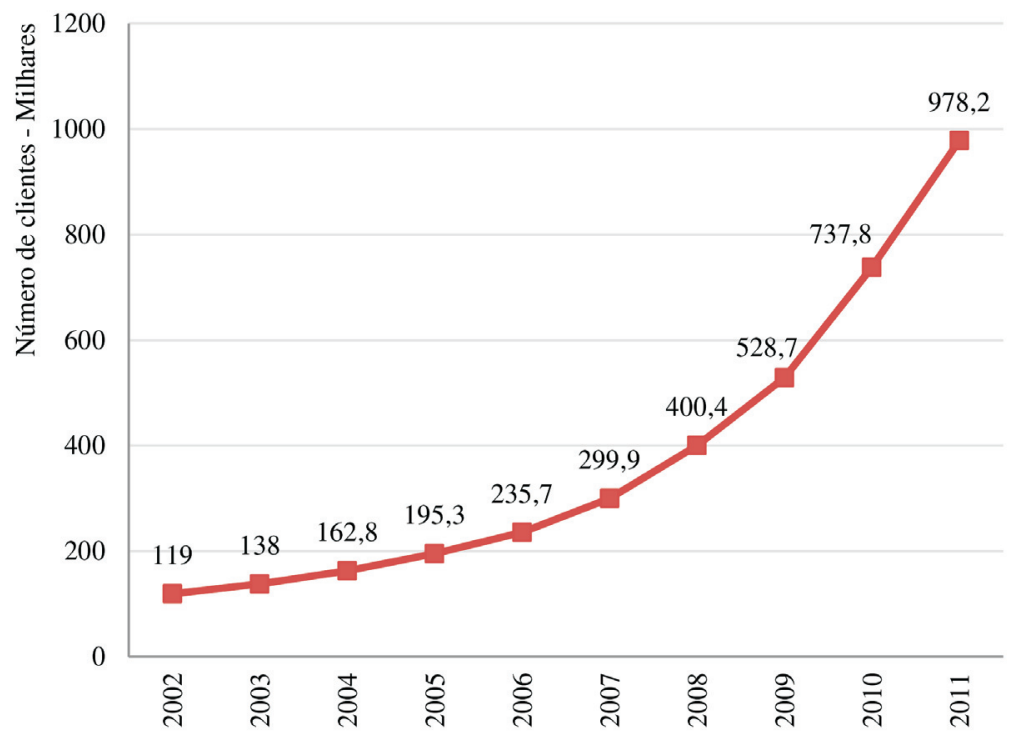

Fonte: BNB (2011).

Gráfico 7 - CrediAmigo: evolução de carteira ativa

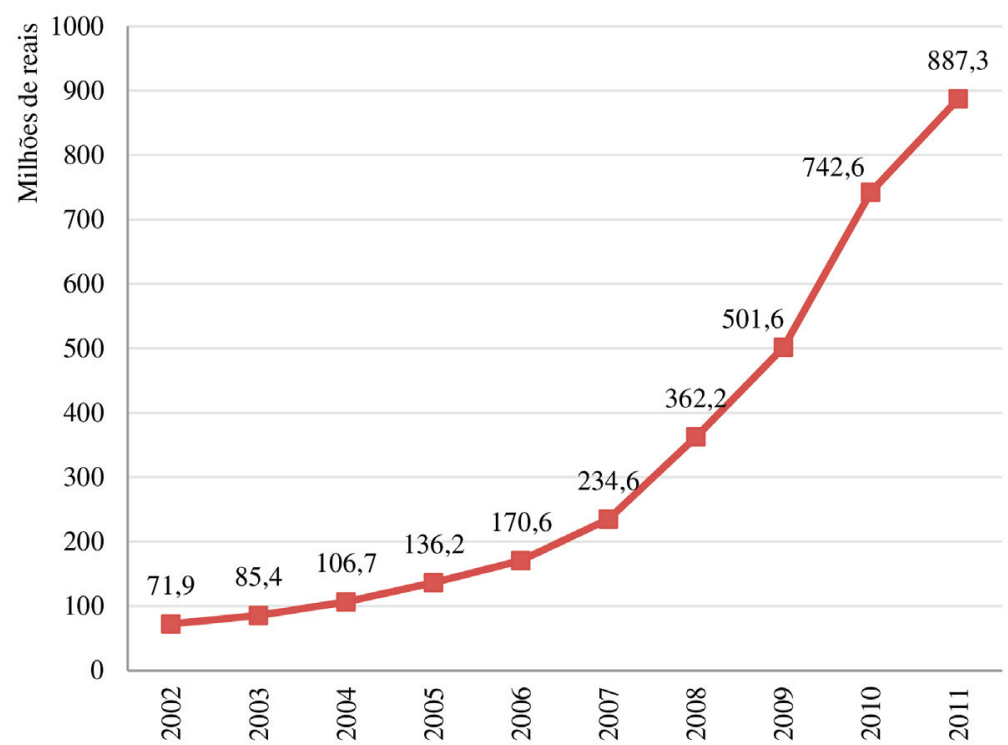

Fonte: BNB (2011). 
Gráfico 8 - CrediAmigo: Total de contratações

- Número de contratações - milhares $\quad$ Montante das contratações - milhares

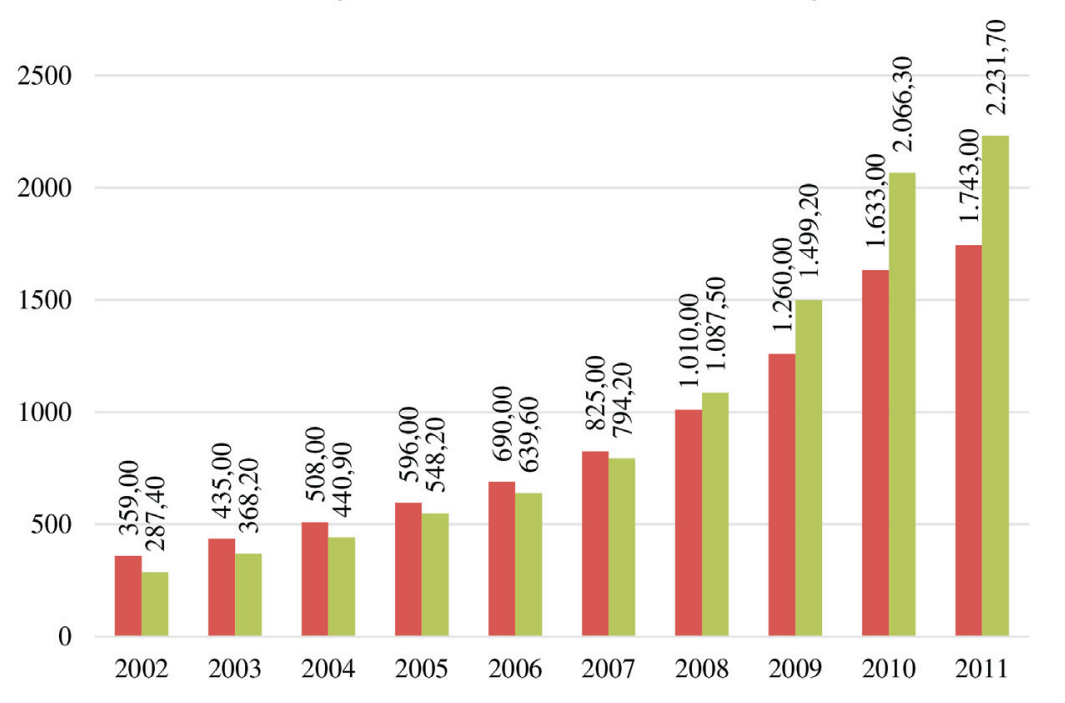

Fonte: BNB (2011).

Gráfico 9 - CrediAmigo: montante médio de empréstimos

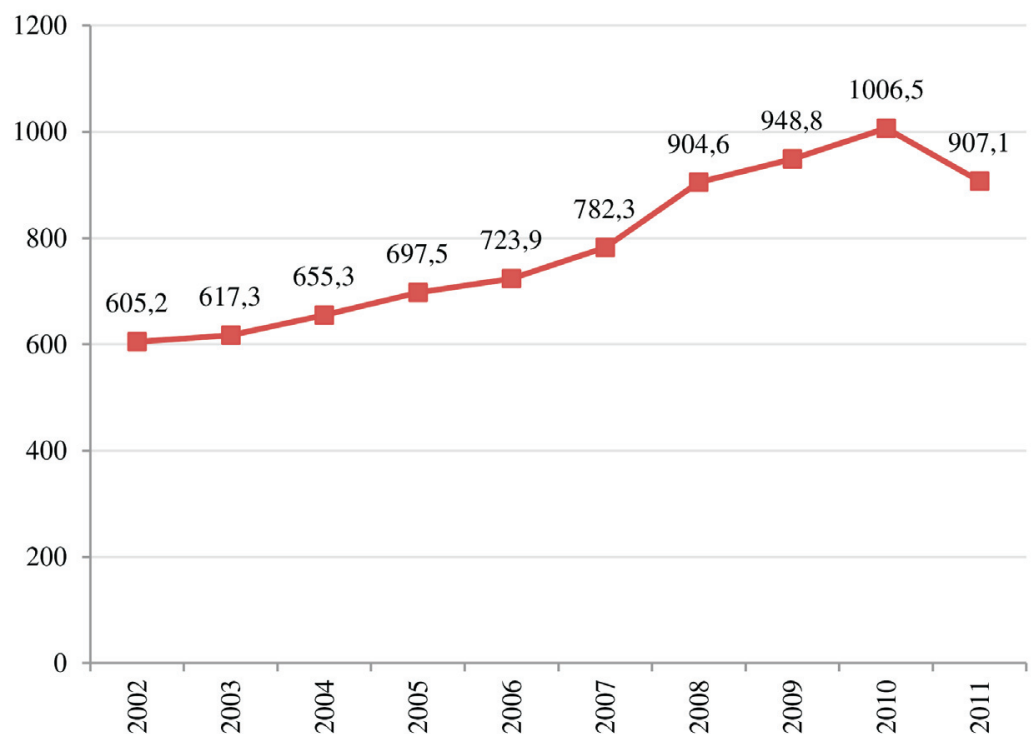

Fonte: BNB (2011).

Instituto de Pesquisa Econômica Aplicada (IPEA) e 48,1\% para a linha de pobreza segundo o salário mínimo legal.

(2) Velocidade de saída da pobreza: indivíduos com mais de cinco anos no programa elevam suas chances de sair da pobreza entre $35,72 \%$ e 40,69\%. Os modelos multivariados de probabilidade linear indicaram que a alta escolarização, domicílio próprio e estrutura de negócio eram fatores que elevavam as chances de saída da pobreza. 
(3) Houve um aumento substancial das variáveis relativas ao desempenho dos negócios dos tomadores de crédito. O impacto geral, em termos de crescimento, foi de $30,7 \%$. As análises constataram um incremento no lucro operacional dos negócios de $36,7 \%$ e um incremento nas vendas de $34,6 \%$.

(4) O capítulo 4, escrito por Neri, avalia o sistema de garantia do CrediAmigo. O colateral social, ou grupo solidário, à luz dos modelos microeconômicos da assimetria de informações (Stiglitz \& Weiss apud Neri 2008), demonstra o poder do capital social em todas suas dimensões (valorativas, institucionais e controle social lateral) como um redutor das incertezas e do risco na operação creditícia (ver Gráfico 8). Neri questiona até onde é replicável a experiência do CrediAmigo, a softtechnology (metodologia) que envolve o banco, o agente do crédito, o tomador e o grupo solidário, para outros contextos culturais brasileiros. Do ponto de vista sociológico, esta pergunta admite duas linhas de resposta: por um lado, as organizações sociais não são passíveis de ser reproduzidas como sementes num viveiro, pois a reprodução do contexto social, particularmente o universo normativo e de valores, não acontece por desenho humano; por outro, o desenho institucional e organizacional supõe um processo de aprendizado, tal qual o caso do CrediAmigo, até encontrar o formato de operação que se ajusta à natureza intrínseca do negócio. Isto será exposto ao longo do presente trabalho (Gráfico 10 e Gráfico 11).

\section{O programa Crescer: mudanças do microcrédito em 2011}

9 O lançamento do crescer foi precedido por longas consultas aos responsáveis do $\mathrm{BNB}$ e do INEC em Fortaleza (CE), conforme declarado aos autores em visita técnica ao $\mathrm{BNB}$
Inspirado no sucesso do CrediAmigo - um milhão de clientes em 10 anos - o Governo Federal relançou o PNMPO em agosto de 2011, agora denominado Crescer - Programa Nacional de Microcrédito, com a proposta de um "microcrédito com assistência técnica"9. Além de oferecer condições excepcionais para o empréstimo, nesta nova tentativa de melhorar a viabilidade operacional e financeira dos contratos, o governo busca expandir o microcrédito produtivo

Gráfico 10 - CrediAmigo: percentual de inadimplência (1 a 90 dias) sobre carteira ativa até 90 dias

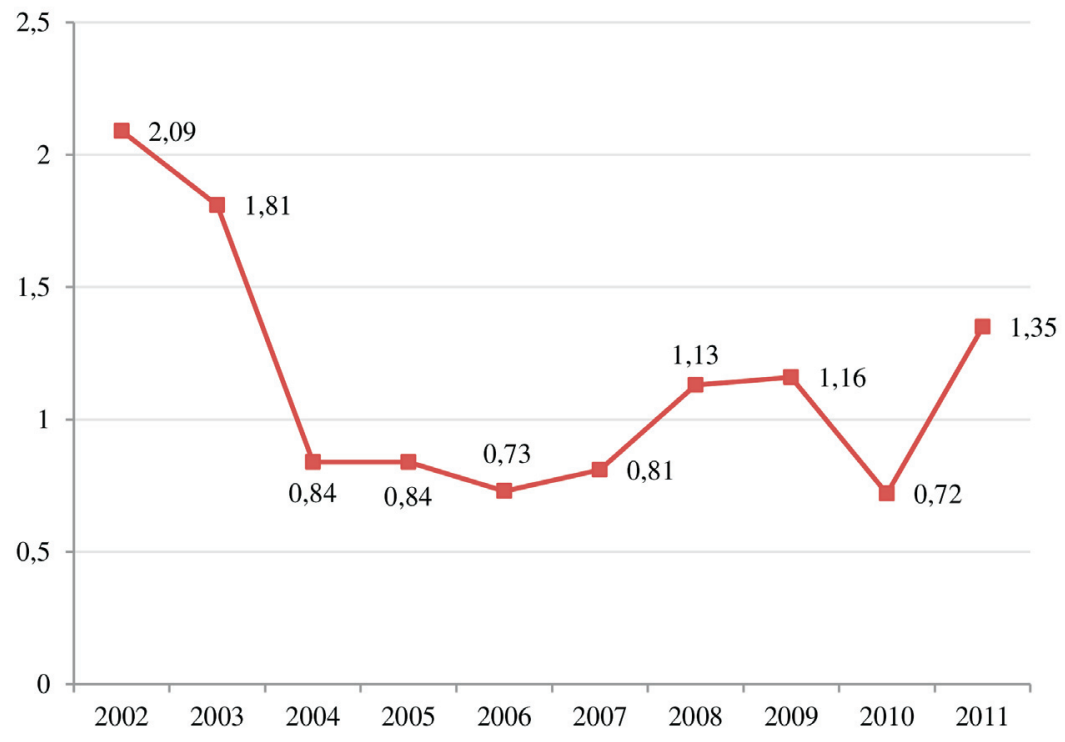

Fonte: BNB (2011). 
Gráfico 11 - CrediAmigo: quantidade de operações

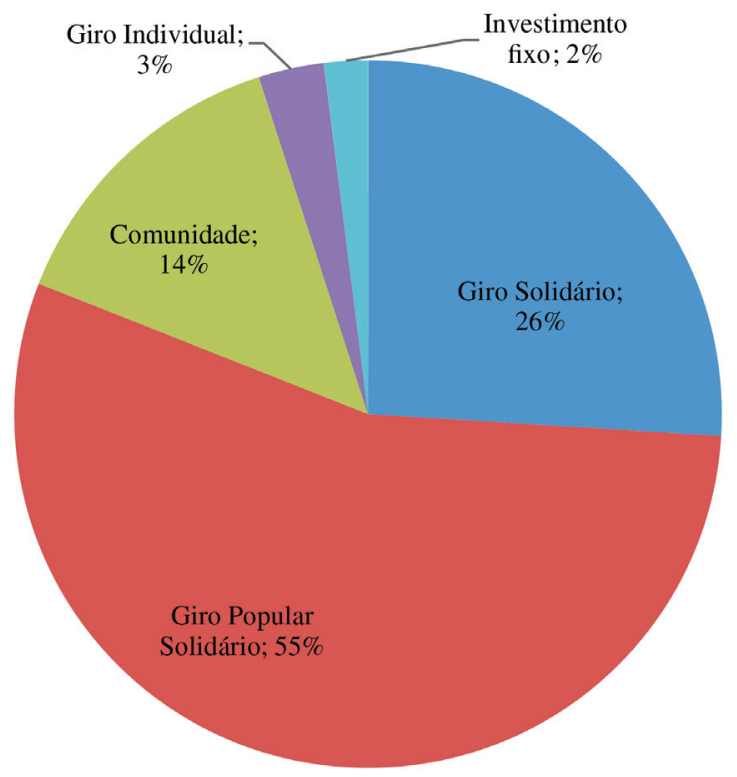

Fonte: BNB (2011).

${ }^{10}$ Como ficará demonstrado, a espinha dorsal da metodologia do CrediAmigo e, portanto, de seu êxito operacional, está no treinamento do agente de crédito. orientado através da figura do agente de crédito ${ }^{10}$. Em seu discurso, durante o lançamento do Crescer, o então Ministro da Fazenda, Guido Mantega, reforçou o papel do microcrédito como porta de saída para as famílias beneficiárias dos programas de transferência de renda condicionada enfatizando a importância de regras mais flexíveis para o setor.

Entre as outras metas do Crescer, expostas por Mantega, está estender o acesso ao crédito a 3,4 milhões de novos clientes até 2013, sem a exigência de garantia dos microempreendedores e a uma taxa de juros de $8 \%$ ao ano, bem abaixo dos quase $60 \%$ ao ano praticado pelas IMFs até o final de 2011. A carteira ativa poderá chegar a três bilhões de reais, sendo administrada pelo BNB, Banco do Brasil, Caixa Econômica Federal e pelo Banco da Amazônia (BASA).

Direcionado aos empreendedores com renda bruta anual de até R \$ 120 mil, o Crescer permite operações até R $\$ 15$ mil e prazos de até 24 meses, com redução da taxa de abertura de crédito (TAC) de $3 \%$ para $1 \%$. São duas as modalidades de crédito: capital de giro e investimentos, sendo o prazo de quatro a seis meses para o capital de giro e de 12 a 24 meses para o de investimentos. A principal fonte de recursos do plano continua a ser os $2 \%$ do compulsório bancário.

Através da MP n ${ }^{\circ} 554$, de 23 de dezembro de 2011, o governo permitiu ao Tesouro Nacional financiar o plano com uma subvenção de até $\mathrm{R}$ \$ 500 milhões por ano, além de oferecer subsídios às instituições privadas que aceitarem operar nas condições estabelecidas pelo plano. O gasto total, previsto para a equalização das taxas, é de R \$ 50 milhões para 2011, R \$ 310 milhões para 2012 e R \$ 483 milhões para 2013. Visando “compensar" a baixa dos juros, o governo se compromete a pagar mensalmente uma parte das taxas de abertura de conta (TAC) aos bancos, com base no valor e prazo praticados nas operações contratadas do segmento produtivo orientado (ver Tabela 1). Essa característica do programa, o subsídio estatal, faz com que o Brasil seja um país onde o mercado das microfinanças esteja sob a tutela do Estado. 
11 A expressão "bancos de primeiro andar" designa as organizações que captam depósitos à vista dos clientes (conta corrente, caderneta de poupança e demais aplicações financeiras) e fazem

empréstimos de consumo, imobiliário e de capital. Já os

bancos de segundo andar,
Para o caso do CrediAmigo um breve excurso é necessário. Podemos constatar, com os dados informados em 2011, que o subsídio governamental de equalização, ou compensação da TAC, não tem um impacto expressivo para que o CrediAmigo possa operar com juros inferiores a $1 \%$, que é a taxa média praticada pelas diversas organizações do mercado (OSCIPS, cooperativas de crédito). A Tabela 2 permite fazer algumas observações sobre o alcance dos novos subsídios e a sustentabilidade financeira do CrediAmigo. Tomemos como exemplo o valor mais alto do crédito para investimento, $\mathrm{R} \$ 8 \mathrm{mil}$ e o maior prazo de retorno, 36 meses. Os $\mathrm{R} \$ 230$ de subsídio correspondem ao 2,9\% do capital, se divididos pelos 36 meses, daria 0,08\% mensais de subsídio. Isto corresponde, em cifras redondas, a um real de subsídio por cada 100 mil emprestados. Esta estimativa permite afirmar que o subsídio é mais um incentivo para o intermediário bancário do que um alívio nas obrigações do tomador. Assim, não encontramos evidência de que a taxa de juros cobrada pelo CrediAmigo, 0,64\%, esteja ancorada no montante do subsídio estatal, pouco expressivo, em lugar de corresponder a uma avaliação real de risco.

Além de se diferenciar do antigo PNMPO pelos atores envolvidos na execução do projeto (os bancos públicos de primeiro andar, como a Caixa Econômica Federal e o Banco do Brasil), o Crescer traz algo novo no cenário do microcrédito: a obrigatoriedade da aplicação dos recursos da exigibilidade ( $2 \%$ do compulsório $)^{11}$. Antes sujeito a diversos entraves burocráticos e sendo mais utilizado para o crédito de consumo, o percentual do compulsório agora deverá ter, no mínimo, $80 \%$ de seu valor aplicado no microcrédito produtivo orientado até julho de 2013, conforme a Medida Provisória no 554, de 23 de dezembro de 2011.

Todas as medidas governamentais, desde a Lei $\mathrm{n}^{\circ}$ 9.790, de 1999, que concedeu a qualificação às organizações de microcrédito, até a Lei $\mathrm{n}^{\circ} 11.110$, que instituiu o PNMPO (agora chamado Crescer), exemplificam a tentativa

Tabela 1 - Equalização por operação contratada do Crescer

\begin{tabular}{llcc}
\hline & & \multicolumn{2}{c}{ Equalização com TAC 1\% } \\
\hline & \multicolumn{2}{c}{$\begin{array}{c}\text { Valor da equalização por } \\
\text { operação contratada }\end{array}$} & \multicolumn{2}{c}{ Prazo da operação } \\
\cline { 3 - 4 } & 100,00 a 499,00 & Menor a 12 meses & Igual ou maior a 12 meses \\
\hline Valor da Operação (em R\$) & 22,00 & 42,00 \\
& 500,00 a 999,00 & 55,00 & 95,00 \\
& $1.000,00$ a 2.999,00 & 85,00 & 125,00 \\
& Igual ou maior a 3.000,00 & 150,00 & 230,00 \\
\hline
\end{tabular}

Fonte: BNB (2011).

Tabela 2 - CrediAmigo/Crescer: condições de crédito

\begin{tabular}{lccc}
\hline Finalidade/garantia & \multicolumn{1}{c}{ Valores } & Encargo & Prazos \\
\hline $\begin{array}{l}\text { Capital de Giro e Investimento } \\
\text { Grupos de 15 a 30 integrantes }\end{array}$ & $\mathrm{R} \$ 100,00$ a $\mathrm{R} \$ 1.100,00$ & & Entre 4 e 12 meses \\
Capital de giro & $\mathrm{R} \$ 100,00$ a $\mathrm{R} \$ 2.000,00$ & $\begin{array}{c}\text { Taxa de juros de } 0,64 \% \text { ao } \\
\text { mês }+\mathrm{TAC} \text { de } 1 \%\end{array}$ & Entre 4 e 12 meses \\
$\begin{array}{l}\text { Grupos de 3 a 10 integrantes } \\
\text { Investimento fixo }\end{array}$ & $\mathrm{R} \$ 300,00$ a $\mathrm{R} \$ 8.000,00$ & & Até 36 meses \\
Individual/Coobrigado & & & \\
\hline
\end{tabular}

Fonte: BNB (2011). 
como o BNDES, não têm a missão de captar recursos dos clientes, somente fornecer crédito para setores estratégicos da economia. estatal de fortalecer o serviço no país - serviço que já foi denominado "mistério brasileiro". Uma das maiores economias globais possui baixa capilaridade de microcrédito, em comparação com os países com níveis de renda similares (Neri 2008). Por isso, torna-se imprescindível o estudo dos mecanismos sociais. Esses mecanismos envolvem as relações próprias do microcrédito, para que este seja aperfeiçoado e amplamente difundido pelo país, visto que hoje é um forte instrumento de inclusão social dos pobres, especialmente as mulheres.

\section{Insulamento burocrático e inserção social do CrediAmigo}

Os estudos de impacto do CrediAmigo exigem ser complementados com uma análise que apresente o cenário de fundo desta iniciativa. É necessário ampliar o olhar sobre esta inovação para entender os pressupostos da intervenção de um banco público, com mandato desenvolvimentista, no mundo da economia popular informal. Com este propósito, invocamos a hipótese-chave de Evans (2004) para explicar o sucesso da intervenção do Estado na hora de alavancar o desenvolvimento econômico.

Segundo Evans, após a queda do muro de Berlim e do fracasso do neoliberalismo manchesteriano, a questão-chave sobre o Estado, em relação à esfera econômica, foi deslocada. Intervir ou não intervir? Essa não é mais a questão. Como intervir? Eis a questão. Quando o Estado assume a sua responsabilidade pela transformação econômica, condensam-se suas três tarefas no mundo moderno: militar, dominação de classe e transformação econômica: "O desempenho econômico é, em si mesmo, uma fonte de legitimidade, além de ser um meio de cumprir os objetivos clássicos de garantir a sobrevivência militar e a ordem interna" (Evans 2004, p.30).

Há, segundo Evans, pelo menos três tarefas que o Estado assume no processo de transformação econômica: (1) acumulação de capital; (2) papel transformador: promover a capacidade empresarial e facilitar a criação de novas forças produtivas; (3) criação de oportunidades e investimento nas capacidades produtivas dos cidadãos.

Com a finalidade de entender melhor a hipótese de Evans, é mister, por um lado, situá-la na tradição da pesquisa brasileira sobre o Estado desenvolvimentista, e, por outro, deslindá-la de outras análises como a coprodução dos bens públicos (Ostrom 1996).

\section{VI.1 Excurso: o Estado desenvolvimentista e a coprodução dos bens públicos}

O debate acadêmico sobre o Estado e sua relação com a sociedade civil e o setor produtivo no Brasil foi dominado por dois diferentes debates, a partir de meados do século XX. O primeiro se deu, particularmente, na Ciência Econômica, entre os defensores do liberalismo - cujos principais representantes foram Eugênio Gudin e Roberto Campos - e a chamada abordagem desenvolvimentista ou "cepalina" (ou, ainda, estruturalista), que contava com um número bastante expressivo de próceres, mas que tinha em Celso Furtado a sua principal liderança intelectual. O segundo debate se deu, nas Ciências Sociais, entre a análise weberiana do Estado brasileiro, desenvolvida a partir da publicação da obra seminal de Raymundo Faoro (1958), Os donos do poder, e a abordagem marxista consolidada a partir dos trabalhos produzidos na Universidade de São Paulo, bem como a partir da obra de Caio Prado Júnior (Sorj 2001; Schwartzman 2003). Uma das mais importantes contribuições da obra de Faoro (1958) se deve a que, em contraste com todas as demais abordagens (tanto na Economia quanto nas Ciências Sociais), ele trouxe a burocracia do Estado para o centro da análise sobre o entendimento dos processos sociais, políticos e econômicos, no Brasil. Faoro (1958) é o primeiro a enxergar a burocracia do Estado brasileiro 
como um corpo autônomo, com capacidades e interesses próprios. Esse corpo de funcionários do Estado, que Faoro chamava de "estamento burocrático", advinha de uma tradição patrimonialista que o Brasil herdara de Portugal.

Como bem ressaltou Schwartzman (2003), o pioneirismo de Faoro não se deveu tanto à aplicação da abordagem weberiana para a análise do Brasil, mas principalmente por ter mostrado a possibilidade de analisar o sistema político por ele mesmo, como uma esfera relativamente autônoma, não como um simples reflexo de interesses de classes, como no marxismo. Pode-se dizer algo semelhante com relação à abordagem dos pensadores liberais, visto que estes percebem o sistema político como puro reflexo de comportamentos oportunistas (rent seeking) de agentes privados. Faoro (1958) inovou também em relação aos teóricos desenvolvimentistas, dado que estes não gestaram uma análise microssociológica do Estado, como a realizada por ele, ao trazer a burocracia para o centro do debate sobre o entendimento da sociedade brasileira e o Estado.

A análise de Faoro, contudo, sofre de certo encarceramento histórico. Para ele, a herança patrimonialista e estamental do Estado brasileiro seria algo intransponível, insuperável. Não é à toa que a abordagem patrimonialista inaugurada por ele ganhou força durante o regime autoritário, pois representava uma importante tese sobre as raízes históricas da tradição autoritária do país (Schwartzman 1988). Contudo, o desenvolvimento do Estado Democrático de Direito, nas últimas décadas, tem levado à superação dessa abordagem, que hoje se mostra, na melhor das hipóteses, parcialmente válida. Embora a pesquisa empírica atual (Lazzarini 2011) demonstre a atualidade da concepção inaugurada por Faoro, no que diz respeito à relevância econômica da burocracia do Estado brasileiro, a forma como esta se conecta com o setor produtivo é vista atualmente a partir de uma ótica bastante diversa. Musacchio e Lazzarini (2014) identificam o Brasil como um dos mais importantes casos de "capitalismo de Estado", enxergando o BNDES como um caso paradigmático de burocracia profissional. Mazzucato (2014), por sua vez, identifica nos bancos de desenvolvimento brasileiros (entre os quais estão o BNDES e, também, o BNB, objeto de nossa análise empírica) casos exemplares de empreendedorismo estatal.

\begin{abstract}
"Investimentos visionários estão sendo feitos atualmente por bancos de investimentos estatais em países como Brasil e China - não apenas fornecendo empréstimos contracíclicos, como também dirigindo esses empréstimos para áreas novas e cheias de incertezas, que os bancos privados e os investidores capitalistas (IC) temem" (Mazzucatio 2014, p.28; grifo no original).
\end{abstract}

Adicionalmente, algumas análises empíricas mostram que o desenvolvimento institucional do Estado brasileiro e a profissionalização de sua burocracia estão em um nível médio-alto (Evans \& Rauch 1999; Bersch, Praça \& Taylor 2013), superior aos países latino-americanos em geral.

Para evitarmos equívocos, também é pertinente deslindar a hipótese do insulamento das burocracias públicas do conceito de coprodução utilizado por Ostrom (1996) ${ }^{12}$. Segundo esta, a superação do "great divide" entre agentes públicos e comunidades locais exige a busca criativa de instituições que desatem ação coletiva em prol da produção de bens públicos. Como ilustração é citada a iniciativa do engenheiro José Carlos de Melo, funcionário na empresa de saneamento local de Recife (PE), que, nos anos 1980, conseguiu construir redes de esgoto de baixo custo com o concurso das comunidades beneficiárias. A empresa pública entrou com o desenho técnico das obras, adaptadas às necessidades das comunidades, e os moradores com o trabalho braçal e pequenos aportes financeiros por família para a implementação e manutenção da obra.

\footnotetext{
12 Evans (1996) refere-se à ideia de coprodução com o termo alegórico "sinergia". Porém, não acrescenta em termos analíticos à problemática apontada por Ostrom (1996). No presente trabalho optamos por invocar a ideia do insulamento burocrático como um conceito mais adequado à realidade dual das burocracias do
} 
CrediAmigo: por um lado, público-estatutárias, e, por outro, celetistas.
O esquema foi um verdadeiro arranjo participativo entre burocratas públicos e comunidades locais beneficiárias do serviço de esgoto. Porém, a ideia de coprodução, nos termos da experiência analisada por Ostrom, não é válida vis a vis para o CrediAmigo. Sendo fiéis ao framework da escola de Indiana (Bromley 1992), devemos levar em conta que a natureza intrínseca do bem público ou coletivo condiciona o desenho técnico e o arranjo institucional que permite a sua produção. O serviço de microcrédito impõe condições de participação diferentes daquelas que podem ser encontradas na ação coletiva que visa construir um sistema de esgotos. Em que sentido o agente de crédito e o tomador individual do empréstimo estabelecem uma relação coprodutiva de um bem público? Em que medida o agente do BNB contribui para a solução do dilema de ação coletiva quando opera créditos individuais? O que há em comum entre um serviço público de coleta de esgotos e o financiamento de pequenos negócios? A separação de direitos e obrigações individuais é muito mais elusiva numa obra de saneamento básico que num contrato individualizado de microcrédito. Ainda que imbuído de espírito público, ao buscar melhorar as condições de vida de comerciantes e pequenos empreendedores do setor informal, o CrediAmigo opera numa relação contratual de caráter privado. Não constatamos o que aponta Abramovay (2008) para o crédito rural, onde prima a percepção política, entre os beneficiários, de que se trata de um direito social sem maiores obrigações de devolução, donde a alta inadimplência e as expectativas de renegociação de prazos e condições.

\section{A tipologia de Evans}

A transformação econômica exige um Estado com corpos burocráticos autônomos e, ao mesmo tempo, parceiros do setor produtivo. Caso contrário, por um lado, um Estado puramente autônomo seria centralista e, por outro, um Estado refém das relações sociais não resolveria os problemas da ação coletiva. Tendo em mente esta polaridade, Evans constrói dois tipos puros de Estado em relação ao mundo econômico (Quadro 1).

Munidos dos conceitos de Evans, podemos perguntar em que medida o CrediAmigo constitui um caso de ação estatal-desenvolvimentista conduzida por burocracias eficientes e insuladas e, ao mesmo tempo, parceiras do setor econômico onde atuam?

Quadro 1 - Tipos puros de Estado

\section{Estado desenvolvimentista}

Autônomo e parceiro

Direciona a transformação industrial e é em grande parte responsável pelo desenvolvimento.

\section{Carência de burocracia}

"A organização interna assemelha-se à burocracia weberiana. Recrutamento por mérito, altamente seletivo, e compensações ao longo de carreiras de longo prazo criam uma situação de compromisso e um sentido de coerência corporativa". (Evans 2001, p.37).

Presença de burocracias eficientes e insuladas.

\section{Estado predador}

Estado refém dos interesses privados

Refreia, às custas da sociedade, o processo de desenvolvimento, mesmo em sua dimensão mais estreita de acumulação de capital.

Estimulam o rent seeking ou caçada de rendas (isenções fiscais, informações privilegiadas, ganhos por valorização, etc.).

Ausência de burocracias eficientes e insuladas. 


\section{Evidências de insulamento burocrático no CrediAmigo}

Em 1993, cinco anos antes da criação do CrediAmigo, funcionários do Banco do Nordeste tinham criado o Instituto Nordeste Cidadania (INEC), sediado em Fortaleza (CE), em 1996. O Instituto se transformou em ONG e em 2003 virou Oscip - ano em que firmou parceria com o CrediAmigo Sua atuação está estreitamente vinculada ao CrediAmigo. Porém, o INEC não trabalha somente com o programa de microcrédito. Entre seus parceiros estão fundações, institutos e universidades. O INEC oferece capacitações, cria cursos, oficinas, panfletos e materiais impressos dirigidos à população de baixa renda. Está presente em 11 estados de atuação do BNB, abrangendo, entre outros, o norte de Minas Gerais e o Espírito Santo. Pelo seu mandato, sempre está em busca dos municípios com piores índices de desenvolvimento humano. Através da parceria com o INEC, firmada em 2003, o CrediAmigo viu ampliada a sua área atuação.

Em 2009, o CrediAmigo replica o esquema através de parceria com a Oscip VivaCred, fato que lhe permitiu chegar ao Rio de Janeiro, atuando nas comunidades de baixa renda das regiões do Centro, Oeste, Rocinha, Maré, Jacarepaguá e São Gonçalo. O INEC e a VivaCred garantem um insulamento burocrático de dupla face para levar adiante a operação de microcrédito. Isto é, por um lado, permitem a seleção, treinamento, promoção e avaliação das "burocracias descalças" que demanda a operação de crédito em setores populares. Os agentes de carreira do BNB, de paletó e gravata, dificilmente poderiam assumir a tarefa de agentes de crédito em bairros da periferia das grandes cidades do Nordeste ou nas ruas onde se desenvolve o comércio informal. Por outro lado, a estrutura organizacional do CrediAmigo garante que quadros de carreira do BNB estejam no controle de decisões estratégicas do negócio com critério empresarial.

Aqui está um dos elementos-chave do CrediAmigo: o BNB criou seu alter ego burocrático, que lhe permite estar a salvo das limitações de seus próprios funcionários de carreira, incentivados pela estabilidade laboral e treinados para interagir com agentes econômicos do setor formal. Mas, ao mesmo tempo, criou as condições para que uma burocracia atípica, a dos agentes de crédito, possa fazer a inserção social que demanda a parceria com setores populares.

Em síntese, o BNB é uma burocracia profissional. O fato de que o BNB seja o responsável pela coordenação do CrediAmigo, assim como do INEC, constitui a condição de possibilidade da autonomia burocrática de todo o processo administrativo (Quadro 2). Os profissionais do BNB possuem altas competências técnicas e são recrutados mediante um exigente e competitivo processo de seleção. Possuem estabilidade em seus cargos e alto nível de autonomia. Estas características os tornam independentes e os protegem de pressões políti-

Quadro 2 - Atribuições na parceria BNB-INEC/VivaCred

\begin{tabular}{ll}
\hline Responsabilidades do BNB & Responsabilidades das ONGs (INEC -VivaCred) \\
\hline • Estabelecer as estratégias e metas & - Selecionar e contratar agentes de crédito \\
- Elaborar e manter manuais normativos & $\begin{array}{l}\text { Operacionalizar os produtos e serviços do pessoal em cam- } \\
\text { po }\end{array}$ \\
- Definir produtos e serviços oferecidos & $\bullet$ Monitorar o processo metodológico \\
- Estabelecer e atualizar processo metodológico & - Avaliar a operação e desempenho dos coordenadores e \\
- Decisão de crédito no nível de captação do funding & assessores de crédito \\
\hline
\end{tabular}

Fonte: BNB (2011). 
cas. É bastante plausível inferir que mecanismos de isomorfismo (DiMaggio \& Powell 1983) institucional joguem um papel importante no processo organizacional que conduz à autonomia burocrática do INEC e do CrediAmigo (Quadro 2).

Do ponto de vista operacional, os postos de atendimento do CrediAmigo estão separados das agências do Banco do Nordeste, como forma de reduzirem a distância com os clientes, para conhecê-los de perto em seu lugar de trabalho. Mas, ao mesmo tempo, a infraestrutura das agências serve como base de funcionamento de unidades de operação de ordem superior. O território urbano, onde atua o programa, é dividido em unidades regionais, sediadas numa agência do BNB, cada uma das quais atende vários postos. Por exemplo, a cidade de Fortaleza está dividida em quatro unidades. Só a unidade do setor Montese, com seis postos de atendimento, possui uma carteira de $\mathrm{R} \$ 22$ milhões e 22 mil clientes ativos. Os postos estão situados nos bairros onde atuam, com instalações adaptadas ao perfil dos clientes: um ambiente mais familiar, menos formal, inclusive com mesas para o atendimento dos grupos solidários.

\section{A espinha dorsal da inserção social do CrediAmigo}

O INEC possui um plano de incentivos para os operadores diretos do microcrédito (coordenadores de unidade, coordenadores de posto e assessores de crédito), onde a mobilidade varia conforme as metas alcançadas. Segundo dados coletados em visita técnica à sede do CrediAmigo em Fortaleza (CE), conseguimos entender de perto o plano de incentivos. Por exemplo, o coordenador de uma unidade, na cidade de Fortaleza, pode ter um salário líquido mensal de R \$ 12 mil, sendo responsável por uma carteira ativa de R \$ 22 milhões. Um coordenador de posto, subordinado à unidade, pode receber um salário de R \$ 5 mil, sendo responsável pelo trabalho de seis assessores de crédito. Os assessores de crédito, guardiões do êxito da operação junto aos tomadores, recebem bonificações quando atingem determinado número de clientes ou quando mantêm baixa a inadimplência. Para serem contratados, os assessores de crédito devem ter, no mínimo, o ensino médio completo. O salário básico inicial, em média, é de R \$1,5 mil, aumentando conforme a carteira de clientes, além de uma série de auxílios (alimentação, universidade, transporte, creche e plano de saúde). Um assessor experiente, com oitocentos clientes e $\mathrm{R} \$ 800$ mil de carteira ativa (não é permitido ultrapassar esses limites), pode receber um ingresso mensal líquido, fora os auxílios, de R\$ 3 mil.

A seleção dos agentes de crédito (no jargão interno, "assessores") é rigorosa. O INEC treina o candidato durante três meses e, no quarto, se contratado, ele recebe uma pequena carteira de clientes. A cada 125 clientes, o assessor sobe um nível. A carreira prevê sete níveis para assessores e 11 níveis no total até chegar ao mais alto escalão de coordenação, sendo que apenas os coordenadores perdem níveis caso o rendimento for baixo. O INEC contrata sob o regime da Consolidação das Leis Trabalhistas (CLT), regime próprio dos trabalhadores do setor privado. Isto significa que seus contratados não desfrutam da estabilidade dos funcionários de carreira do BNB, estes são considerados burocratas de Estado. Em compensação, o INEC oferece bonificações e incentivos salariais flexíveis que atendem às expectativas dos candidatos a assessores de microcrédito. Muitos deles procedem do mesmo universo cultural de seus clientes, moram nos mesmos bairros e favelas onde desempenham seu ofício. Contratar e demitir funcionários, segundo seu desempenho, é um assunto bastante flexível para o INEC, algo que não aconteceria com funcionários de carreira do BNB. O esquema de parceria BNB-INEC para operacionalização da carteira de crédito junto aos empreendedores do setor informal é um determinante no êxito de CrediAmigo. 
Os assessores ficam de $08 \mathrm{~h} 30$ às $16 \mathrm{~h}$ em campo, realizando visitas, fazendo prospecção de clientes, divulgando o CrediAmigo etc. Eles ficam à disposição dos clientes 24 horas por dia. Após as $16 \mathrm{~h}$ todos retornam às suas unidades para que seja feito o comitê de crédito. No comitê são avaliadas as propostas de novos clientes, todos votam, num quorum ímpar, menos o assessor que apresentou a proposta ao grupo (Gráfico 12).

No CrediAmigo, considera-se inadimplente qualquer cliente com um dia de atraso em suas parcelas. Há a cultura de inadimplência zero, onde se valoriza a cobrança permanente dos clientes. Os assessores fazem uma visita no dia anterior ao vencimento da parcela. Se acontece atraso, voltam imediatamente um dia depois para verificar o motivo do não pagamento. Impera um espírito de parceria, onde "não queremos endividar o cliente, mas crescer com ele", diz um funcionário do Banco.

Sobre a formalização, não há um esforço explícito por parte do CrediAmigo em incentivar a regularização dos empreendimentos. E, em relação às atividades ilegais, como venda de CDs e DVDs piratas, os assessores não chegam nem a fazer a análise de crédito. O CrediAmigo busca se inserir nos ambientes íntimos dos clientes: em festas locais, nas reuniões de grupos de venda de produtos de porta em porta (Natura, Avon, Hermès etc.). Até no ambiente escolar, distribuindo pirulitos nas escolas para que as crianças levem o folheto a seus pais. A prospecção de clientes segue a lógica que os assessores denominam "do caracol", onde busca-se expandir o serviço através de vizinhos e parentes das pessoas atendidas, chegando assim a um círculo cada vez mais amplo mediante as redes pessoais.

A relação entre o assessor e o cliente deve ser bem trabalhada, pois, ao mesmo tempo em que se busca a intimidade, deve-se manter uma atitude profissional. O estreitamento da relação com o cliente é um risco: se o assessor se envolver demais, pode criar um ambiente de reciprocidade, onde favores devem ser obrigatoriamente recompensados. Os clientes são convidados a participarem de cursos gratuitos de capacitação a microempreendedores, com o material "Aprender a empreender" do Serviço Brasileiro de Apoio às Micro e Pequenas Empresas (SEBRAE). Para os clientes evangélicos, foi criado um material impresso denominado "Empreendedorismo sobre uma perspectiva

Gráfico 12 - Pirâmide organizacional do CrediAmigo (número de funcionários em 2011)

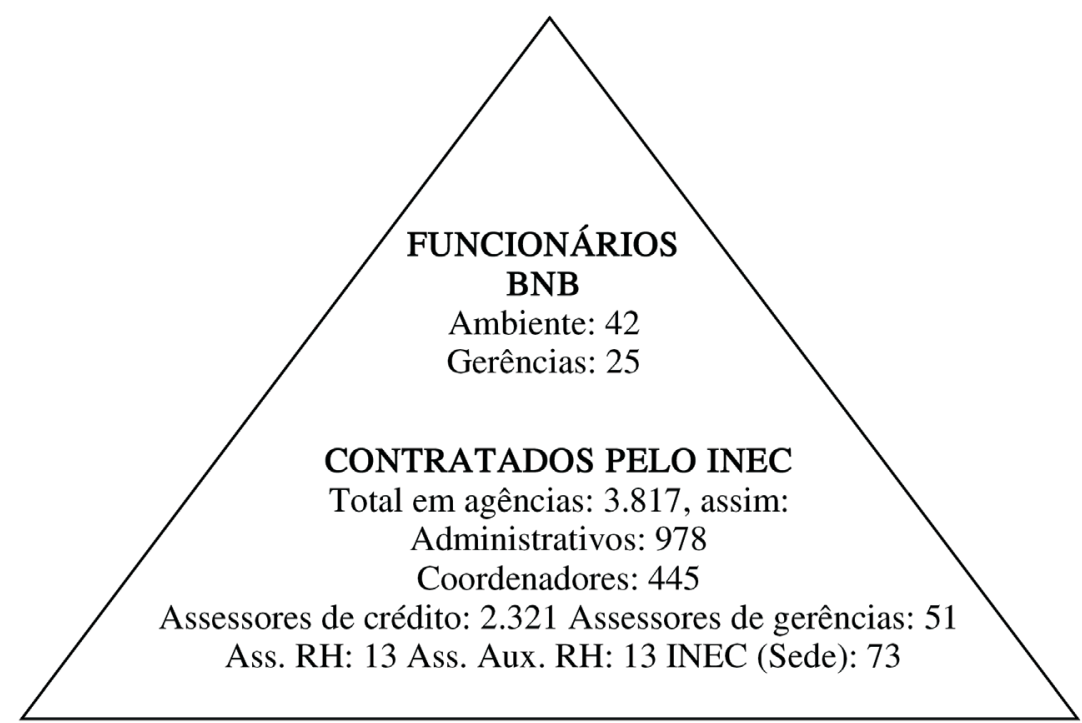

Fonte: Os autores. 
cristã", uma apresentação específica, criada por um assessor que também é pastor, onde a divulgação do programa é explicada com base em passagens bíblicas.

Pelo exposto anteriormente, fica claro o papel fundamental da parceria BNB-INEC para garantir o sucesso do programa. Ao estabelecer parcerias com organizações que já conhecem as comunidades com que se deseja trabalhar, que já têm um histórico de relacionamento com as pessoas do lugar, elevam-se as chances de sucesso na operação de crédito. Além disso, o fato dos assessores serem funcionários das OSCIPs, e não do BNB, faz com que fiquem sujeitos a bonificações e condicionalidades por rendimentos, comprometendo-se mais com o trabalho. Quando uma funcionária do BNB diz que se busca conciliar a visão de banco com o estreitamento da relação com o cliente, fica clara a visão financeira sob controle do BNB, enquanto a linha de frente (o relacionamento) é de responsabilidade do INEC e do VivaCred.

Se, por um lado, o BNB representa a principal base da autonomia burocrática do programa CrediAmigo, por outro o INEC permite a sua inserção social. A rigidez do BNB representaria uma barreira para o funcionamento adequado do programa, dado que o BNB não tem o enraizamento necessário nas comunidades que são alvo do programa. Em contraste, a flexibilidade de uma Organização Não Governamental como o INEC torna possível a identificação de clientes para o programa. $\mathrm{O}$ fato de que os operadores do INEC são majoritariamente membros das comunidades-alvo torna mais fácil identificar os potenciais clientes, elevando, assim, a eficiência do programa. Esses operadores não poderiam ser contratados por uma organização tão rígida quanto o BNB.

\section{Conclusões}

O percurso, aqui exposto, pelo desenho da política pública brasileira para o microcrédito e pela operação do CrediAmigo permite tirar várias conclusões e, ao mesmo tempo, levantar perguntas sobre as possibilidades de reprodução da experiência.

a) O novo marco regulatório do microcrédito brasileiro, o Programa Crescer, traça metas ambiciosas que estão sustentadas num maciço apoio do setor público mediante subsídios às operações de microcrédito. Podemos afirmar que o mercado das microfinanças é altamente tutelado pelo Estado brasileiro.

b) A existência de grandes bancos estatais é um fator de intervenção com o qual o governo brasileiro quer alavancar a expansão do microcrédito produtivo e orientado. Neste sentido, o Programa Crescer visa replicar, em grande escala, a experiência do CrediAmigo/BNB, obrigando que os outros bancos públicos, em particular o Banco do Brasil e a Caixa Econômica Federal, entrem no negócio do microcrédito. Aqui se levantam as seguintes perguntas: poderão estes bancos, com corpos burocráticos rígidos, reproduzir o desenho flexível do CrediAmigo? Poderão aprender, em quatro anos, o que o BNB levou mais de uma década? Eis alguns desafios práticos que deverão ser encarados pelo voluntarismo político que anima o Programa Crescer.

c) O relativo sucesso do programa CrediAmigo resulta de um desenho institucional original e exitoso. De um lado, há uma típica burocracia profissional que é a base da necessária autonomia burocrática e estabilidade organizacional do programa. De outro lado, há uma Organização Não Governamental com elevado grau de flexibilidade e raízes profundas com as comunidades alvo do programa. A relação harmo- 
niosa entre essas duas organizações leva a níveis elevados de eficiência, por um lado, e de focalização da política, por outro.

Uma importante contribuição que consideramos ser trazida pelo presente trabalho é a de demonstrar a aplicabilidade da abordagem institucionalista de Evans (2004) para a análise de políticas de desenvolvimento bastante diferentes das políticas industriais, que foram aquelas sobre as quais ele se debruçou em seu estudo. Podemos ver que um desenho institucional exitoso - que permita uma sinergia virtuosa entre Estado e sociedade civil - pode levar a excelentes resultados em políticas de desenvolvimento com perfil popular, ou seja, polí-

13 Para resultado semelhante, ticas de desenvolvimento de base ${ }^{13}$.

ver Lam (1996).

Silvio Salej Higgins (sisahi@yahoo.com) é Doutor em Sociologia pela Universidade de Paris Dauphine (França) e pela Universidade Federal de Santa Catarina (UFSC) e Professor do Departamento de Sociologia da Universidade Federal de Minas Gerais (UFMG). Vínculo institucional: Departamento de Sociologia, UFMG, Belo Horizonte, MG, Brasil.

Jorge Alexandre Barbosa Neves (jorgeaneves@gmail.com) é Doutor em Sociologia pela Universidade de Wisconsin, Madison (EUA) e Professor do Departamento de Sociologia da Universidade Federal de Minas Gerais (UFMG). Vínculo institucional: Departamento de Sociologia, UFMG, Belo Horizonte, MG, Brasil.

\section{Referências}

Abramovay, R., 2008. Alcance e limites das finanças de proximidade no combate à inadimplência: o caso do Agroamigo. Texto para discussão n. 10. São Paulo: Fundação Instituto de Pesquisas Econômicas.

Barone, F.M. \& Martinez, R., 2009. Microfinanças no Brasil e na América Latina. In L.E. Feltrim; E.C.F. Ventura \& A.B. DodL. Perspectivas e desafios para inclusão financeira no Brasil: visão de diferentes atores. Brasília: Banco Central do Brasil.

Bates, R.H, 2005. Beyond the Miracle of the Market. The Political Economy of Agrarian Development in Kenya. New York: Cambridge University Press.

Bersch, K.; Praça, S. \& Taylor, M., 2013. State Capacity and Bureaucratic Autonomy within National States: Mapping the Archipelago of Excellence in Brazil. In The Latin American Studies Association Conference. Washington, D.C.

Block, F., 1988. Revising State Theory. Philadelphia: Temple University Press.

Block, F. \& Evans, P., 2005. The State and the Economy. In R. Swedberg \& N. Smelser, eds. Handbook of Economic Sociology. New York: Princeton University Press.

Bromley, D., 1992. Making the Commons Work. Theory, Practice and Policy. San Francisco: ICS Press.

Daley-Harris, S., 2007. State of the Microcredit Summit Campaign Report 2007. Disponível em: www.microcreditsummit.org. Acesso em: 5 jul. 2016.

De Soto, H., 2001. O mistério do capital. Rio de Janeiro: Record.

DiMaggio, P. \& Powell, W., 1983. The Iron Cage Revisited: Institutional Isomorphism and Collective Rationality in Organizational Fields. American Sociological Review, 48(2), pp.147-160. DOI: 10.2307/2095101

Evans, P., 1996. Government Action, Social Capital and Development: Reviewing the Evidence on Synergy. World Development, 24(6), pp.1119-1132. DOI: 10.1016/0305-750x(96)00021-6 2004. Autonomia e parceria. Rio de Janeiro: Editora da UFRJ.

Evans, P. \& Rauch, J., 1999. Bureaucracy and Growth: A Cross-National Analysis of the Effects of ‘Weberian’ State Structures on Economic Growth. American Sociological Review, 64(5), pp.748-765. DOI: 10.2307/2657374

Faoro, R., 1958. Os donos do poder: formação do patronato político brasileiro. Porto Alegre: Editora Globo.

Lam, W. 1996. Institutional Design of Public Agencies and Coproduction: A Study of Irrigation Associations in Taiwan. World Development, 24(6), pp.1039-1054. DOI: 10.1016/0305-750x(96)00020-4

Lazzarini, S., 2011. Capitalismo de laços: os donos do Brasil e suas conexões. Rio de Janeiro: Elsevier.

Mazzucato, M., 2014. O Estado Empreendedor: desmascarando o mito do setor público vs. setor privado. São Paulo: Portfolio-Pinguin.

Mick, J., 2003. O caráter social do crédito: microcrédito, combate à pobreza e desenvolvimento alternativo - a experiência brasileira e o caso Porto Sol (1996-2002). Tese de Doutorado. Florianópolis: Universidade Federal de Santa Catarina.

Musacchio, A. \& Lazzarini, S., 2014. Reinventing State Capitalism: Leviathan in Business, Brazil and Beyond. Cambridge, MA: Harvard University Press.

Neri, M., 2008. Microcrédito, o mistério nordestino e o Grameen brasileiro, perfil e performance dos clientes do CrediAmigo. Rio de Janeiro: Fundação Getúlio Vargas.

Neri, M. \& Da Silva, G., 2005. Negócios nanicos, garantias e acesso ao crédito. Revista de Economia Contemporânea, 9(3), pp.643-669. DOI: 10.1590/s1415-98482005000300007

Ostrom. E. 1996. Crossing the great divide:coproduction, sinergy, and development. World Development, 24(6), p. 1073-1087. DOI: $10.1016 / 0305-750 x(96) 00023-x$ 
Sorj, B., 2001. A construção intelectual do Brasil contemporâneo. Rio de Janeiro: Zahar Editor. Schwartzman, S., 1988. Bases do Autoritarismo Brasileiro. Rio de Janeiro: Editora Campus. 2003. A atualidade de Raymundo Faoro. Dados, 46(2), p.207-213. DOI: 10.1590/s0011-52582003000200001

Yunus, M., 2011. Declaração. In IV Fórum de Comunicação e Sustentabilidade. Belo Horizonte. 26 maio. Yunus, M. \& Jolis, A., 2006. O banqueiro dos pobres. São Paulo: Editora Ática.

Weber, M., 1980. Parlamentarismo e governo numa Alemanha reconstruída. São Paulo: Abril Cultural.

\title{
Outras fontes
}

BNB. Banco do Nordeste do Brasil, 2011. Apresentação do CrediAmigo por Rosa Cristina Lima Ribeiro, Gerente Executiva do Programa CrediAmigo. Visita técnica ao ambiente de microfinança urbana. 24 nov.

Diário das Leis, 2012. Sítio de internet. Disponível em: www.diariodasleis.com.br. Acesso em: 3 jul 2016.

Ministério do Trabalho e Emprego, 2008. Programa Nacional de Microcrédito Produtivo Orientado (PNMPO). Proposta. Disponível em: www.mte.gov.br/ecosolidaria/sies.asp. Acesso em 3 jul. 2016.

2013. Relatório de dados, primeiro trimestre de 2013. www.mte.gov.br/ecosolidaria/sies.asp. Acesso em 3 jul. 2016.

MIX, 2012. MicroBanking Bulletin. Disponível em: www.themix.org. Acesso em: 5 jun. 2016.

SUMMIT CAMPAIGN, 2007. Report. Disponível em: www.microcreditsummit.org. Acesso em: 3 jul 2016.

Bureaucratic autonomy, social embeddedness and public policy in Brazil: The case of CrediAmigo

\begin{abstract}
In this article was analyzed the method of CrediAmigo, Microcredit program of Banco do Nordeste (BNB). We aim to identify the organizational factors that make the proposal viable financially and socially. The paper uses two types of data, secondary on the amounts and default operation (provided by BNB), and primary, built in participatory observation about the order process operation, implementation methodology, customer perceptions. The main finding supports the hypothesis of bureaucratic insulation and social embeddedness (Evans). BNB can only make the operation after a long process of learning where a bureaucratic Ad hoc body, unlike the career employees of the Bank, was created, managed by an NGO (Instituto Nordeste Cidadania INEC), founded by BNB itself. The INEC bureaucracy has a listing of training adapted to the social sectors that alive in the informal economy. The results extend the one-sidedness of others assessment that exists on CrediAmigo (FGV). From the sociological point of view, we conclude that the institutional - organizational dimension is a key factor to explain the feasibility of the operation of microcredit. Far beyond the simple idea that organizations only reduce transaction costs, institutions forge and create learning job skills in their employees.
\end{abstract}

KEYWORDS: Microcredit; Bureaucratic insulation; Social embeddedness; Social Policy; CrediAmigo.

This is an Open Access article distributed under the terms of the Creative Commons Attribution Non-Commercial License which permits unrestricted non-commercial use, distribution, and reproduction in any medium provided the original work is properly cited. 